\title{
Wearing-off at the end of natalizumab dosing intervals is associated with low receptor occupancy
}

Gerd Haga Bringeland, MD, Nello Blaser, PhD, Kjell-Morten Myhr, MD, PhD, Christian Alexander Vedeler, MD, PhD, and Sonia Gavasso, PhD

Neurol Neuroimmunol Neuroinflamm 2020;7:e678. doi:10.1212/NXI.0000000000000678

\author{
Correspondence \\ Dr. Bringeland \\ gerd.haga.bringeland@ \\ helse-bergen.no
}

\section{Abstract \\ Objective}

We aimed to investigate whether wearing-off symptoms at the end of the natalizumab dosing interval were associated with clinical and demographic patient characteristics or natalizumab receptor occupancy $(\mathrm{RO})$ on leukocytes.

\section{Methods}

In this cross-sectional study of 40 patients with relapsing-remitting MS (RRMS) receiving natalizumab at the Department of Neurology, Haukeland University Hospital, we recorded clinical and demographic data including age, body mass index (BMI), working status, smoking habits, disease characteristics, treatment duration, vitamin $\mathrm{D}$ levels, and wearing-off symptoms. We quantified neurofilament light chain in serum and measured natalizumab RO in leukocyte subtypes by high-parameter mass cytometry. Associations with wearing-off symptoms were analyzed.

\section{Results}

Eight (20.0\%) patients who reported regular occurrence of wearing-off symptoms, 9 (22.5\%) who sometimes had wearing-off symptoms, and 23 (57.5\%) who did not have wearing-off symptoms were evaluated. Patients who regularly had wearing-off symptoms had lower natalizumab RO than patients who reported having such symptoms sometimes or never. The former group also had higher BMI and higher frequency of sick leave. High BMI was associated with low RO. No other demographic or disease characteristics were associated with the phenomenon.

\section{Conclusions}

Low RO may explain the wearing-off phenomenon observed in some patients with RRMS treated with natalizumab, and high BMI may be the underlying cause.

From the Neuro-SysMed (G.H.B., K.-M.M., C.A.V., S.G.), Department of Neurology, Haukeland University Hospital, Bergen, Norway; Department of Clinical Medicine (G.H.B., K.-M.M., C.A.V., S.G.), University of Bergen, Bergen, Norway; and Department of Informatics (N.B.), University of Bergen, Bergen, Norway. 


\section{Glossary}

BMI = body mass index; $\mathbf{C D C}=$ conventional dendritic cell; $\mathbf{E I D}=$ extended interval dosing; $\mathbf{P B L}=$ peripheral blood leukocyte; $\mathbf{P M L}$ = progressive multifocal leukoencephalopathy; RRMS = relapsing-remitting MS; RO = receptor occupancy.

Natalizumab (Tysabri ${ }^{\circledR}$, Biogen, Cambridge, MA) is a therapeutic monoclonal antibody used to treat patients with relapsing-remitting MS (RRMS). It prevents leukocyte migration across the blood-brain barrier into the CNS by binding to the $\alpha 4$ subunit of the $\alpha 4 \beta 1$ integrin ( $\alpha 4$ integrin) on leukocyte surfaces. ${ }^{1}$ Natalizumab is administered IV at a standard dose of $300 \mathrm{mg}$ every 4 weeks.

Although highly efficacious in preventing disease activity, many patients report the so-called wearing-off symptoms at the end of the 4-week dosing interval. Although wearing-off symptoms are often reported, only a few previous studies have described the phenomenon, and little is known about the underlying causes of these symptoms. ${ }^{2-5}$

Natalizumab receptor occupancy ( $R O)$ is defined as the level of natalizumab bound to $\alpha 4$ integrin on leukocytes and is a potential biomarker to monitor and individualize natalizumab therapy. ${ }^{6} \mathrm{RO}$ has traditionally been measured with flow cytometry. Mass cytometry is a novel technology for highparameter single-cell analysis. For mass cytometry, detection antibodies are conjugated to metals instead of fluorophores, allowing analysis of over 40 parameters simultaneously on single cells. ${ }^{7}$ This permits measurement of RO in conjunction with more markers and in more cell types of interest than is currently possible by flow cytometry. We aimed to investigate whether clinical and demographic patient characteristics or natalizumab RO were associated with the wearing-off phenomenon by using high-parameter mass cytometry to measure natalizumab RO in patients with RRMS treated with natalizumab who do and do not report wearing-off symptoms at the end of dosing intervals.

\section{Methods}

\section{Patients}

We invited all patients older than 18 years with a diagnosis of RRMS who had received a minimum of 6 natalizumab infusions at the Department of Neurology, Haukeland University Hospital $(n=45)$ to participate in this cross-sectional study; 40 agreed to participate. At inclusion, we obtained baseline demographic and clinical patient characteristics from the patients' medical journal including age, sex, disease duration (years since first MS symptoms), natalizumab treatment duration (years since first natalizumab infusion), numbers of new MRI lesions and clinical relapses in the last year before inclusion, serum vitamin D level, Symbol Digit Modalities Test score, ${ }^{8}$ and Expanded Disability Status Scale score. ${ }^{9}$ Each patient filled in questionnaires on fatigue (Fatigue Severity Scale), ${ }^{10}$ and on working status, smoking habits, weight, height, and whether they had wearing-off symptoms (never, sometimes, and regularly), and, if applicable, type of symptoms.

\section{Standard protocol approvals, registrations, and patient consents}

The study was approved by the Regional Committee for Medical Research Ethics, Western Norway (REK 2016/579), and written informed consent was obtained from all participating patients.

\section{Blood samples}

At inclusion, we collected blood before and after natalizumab infusion. For mass cytometry analysis, whole blood was collected in heparinized Vacutainer tubes (Greiner Bio-One $\mathrm{GmbH}$, Kremsmünster, Austria), incubated with Proteomic Stabilizer (Smart Tube, Inc, San Carlos, CA) for 10 minutes, and stored at $-80^{\circ} \mathrm{C}$. Whole blood was then thawed, and red blood cell lysis was performed with Thaw-lyse buffer I (Smart Tube, Inc) to obtain peripheral blood leukocytes (PBLs). For neurofilament measurement, whole blood was collected in Vacutainer tubes with no additives (BD, Plymouth, United Kingdom), incubated at room temperature for 60 minutes, and centrifuged at room temperature at $3,200 \mathrm{~g}$ for 13 minutes before the serum was retrieved and stored at $-80^{\circ} \mathrm{C}$.

\section{Neurofilament measurement}

Serum samples were thawed, and the concentration of neurofilament light chain (NF-L) was measured with a singlemolecule array (Simoa) assay (Quanterix, Billerica, MA) according to the manufacturer's protocol.

\section{Mass cytometry RO assay}

PBLs were stained with a 36-parameter mass cytometry antibody panel (table e-1, links.lww.com/NXI/A190). Bound natalizumab was detected with an anti-IgG4 antibody (conjugated to $\left.{ }^{169} \mathrm{Tm}\right)$. Total $\alpha 4$ integrin was detected with an anti-CD49d antibody (conjugated to ${ }^{141} \mathrm{Pr}$ ) specific for a different epitope than natalizumab. The 36 metal-conjugated antibodies were purchased preconjugated (Fluidigm, South San Francisco, CA), or antibodies were purchased (BioLegend, San Diego, CA, R\&D Systems, Minneapolis, MN, and Abcam, Cambridge, Great Britain) and conjugated in-house to metals with the Maxpar Antibody Labeling Kit (Fluidigm). Briefly, we thawed, barcoded (Cell-ID 20-Plex Pd Barcoding Kit, Fluidigm), and pooled PBL samples in batches of 20 randomly distributed samples, keeping paired samples from the same patients in the same batch. A control PBL sample from 1 healthy donor was included in each batch. Pooled PBLs were first incubated in Maxpar cell stain buffer with 100 $\mathrm{U} / \mathrm{mL}$ heparin (LEO Pharma A/S) for 20 minutes at room temperature ${ }^{11}$ and then incubated with the antibody cocktail 
Table 1 Demographic and clinical characteristics of patients with RRMS and the frequency of wearing-off symptoms

\begin{tabular}{|c|c|c|c|c|c|c|}
\hline & \multirow[b]{2}{*}{ Total } & \multicolumn{5}{|c|}{ Wearing-off symptoms } \\
\hline & & Never & Sometimes & Regularly & $\stackrel{p}{\text { Value }^{a}}$ & $\begin{array}{l}p \text { Value (age } \\
\text { adjusted) }^{\mathrm{b}}\end{array}$ \\
\hline Patients with RRMS, n (\%) & $40(100)$ & $23(57.5)$ & $9(22.5)$ & $8(20.0)$ & & \\
\hline Age, y & $43.0(34.0-49.3)$ & $\begin{array}{l}45.0 \\
(35.5-52.0)\end{array}$ & $\begin{array}{l}34.0 \\
(31.0-51.0)\end{array}$ & $\begin{array}{l}43.0 \\
(37.0-43.8)\end{array}$ & 0.382 & - \\
\hline Sex, female, n (\%) & $25(62.5)$ & $15(65.2)$ & $3(33.3)$ & $7(87.5)$ & 0.069 & 0.063 \\
\hline Height, cm & $171(166-179)$ & $169(165-173)$ & $180(177-182)$ & $171(167-173)$ & 0.078 & 0.047 \\
\hline Weight, kg & $75.0(67.0-82.5)$ & $\begin{array}{l}75.0 \\
(60.0-79.5)\end{array}$ & $\begin{array}{l}73.0 \\
(67.0-82.0)\end{array}$ & $\begin{array}{l}81.5 \\
(76.5-87.8)\end{array}$ & 0.107 & 0.022 \\
\hline BMI & $25.3(22.6-27.2)$ & $\begin{array}{l}25.1 \\
(22.2-26.6)\end{array}$ & $\begin{array}{l}23.9 \\
(22.5-25.2)\end{array}$ & $\begin{array}{l}27.8 \\
(26.5-31.2)\end{array}$ & 0.023 & 0.006 \\
\hline Current smoker, n (\%) & $7(17.5)$ & $4(17.4)$ & $2(22.2)$ & $1(12.5)$ & 0.873 & 0.860 \\
\hline Sick leave, n (\%) & $9(22.5)$ & $2(8.7)$ & $3(33.3)$ & $4(50.0)$ & 0.04 & 0.013 \\
\hline Disease duration, y & $13.0(8.0-17.0)$ & $13.0(8.0-17.5)$ & $\begin{array}{l}13.0 \\
(8.0-17.0)\end{array}$ & $12.5(8.8-16.0)$ & 0.949 & 0.798 \\
\hline Treatment duration, y & $4.0(3.0-7.3)$ & $4.0(3.0-8.5)$ & $5.0(3.0-6.0)$ & $4.5(2.0-8.0)$ & 0.999 & 0.904 \\
\hline Dose number & $56.5(39.0-102.3)$ & $\begin{array}{l}49.0 \\
(39.0-107.5)\end{array}$ & $\begin{array}{l}69.0 \\
(41.0-78.0)\end{array}$ & $\begin{array}{l}63.5 \\
(33.5-111.8)\end{array}$ & 0.974 & 0.816 \\
\hline Days since last dose & $28.0(28.0-28.0)$ & $\begin{array}{l}28.0 \\
(28.0-28.5)\end{array}$ & $\begin{array}{l}28.0 \\
(28.0-28.0)\end{array}$ & $\begin{array}{l}28.00 \\
(27.0-28.0)\end{array}$ & 0.358 & 0.375 \\
\hline EDSS score & $2.0(1.0-3.5)$ & $2.0(1.0-3.5)$ & $2.0(1.5-2.5)$ & $2.0(1.5-3.1)$ & 0.880 & 0.682 \\
\hline FSS score & $4.8(3.3-5.7)$ & $4.6(3.3-5.4)$ & $4.3(3.0-6.1)$ & $5.3(4.8-5.8)$ & 0.223 & 0.186 \\
\hline SDMT & $57.0(50.0-67.3)$ & $\begin{array}{l}64.0 \\
(52.5-68.5)\end{array}$ & $\begin{array}{l}58.0 \\
(54.0-64.0)\end{array}$ & $\begin{array}{l}48.5 \\
(45.5-56.0)\end{array}$ & 0.151 & 0.109 \\
\hline $\begin{array}{l}\text { New lesions detected by MRI in last } \\
\text { year }\end{array}$ & $0.0(0.0-0.0)$ & $0.0(0.0-0.0)$ & $0.0(0.0-0.0)$ & $0.0(0.0-0.0)$ & - & - \\
\hline Relapse activity in last year & $0.0(0.0-0.0)$ & $0.0(0.0-0.0)$ & $0.0(0.0-0.0)$ & $0.0(0.0-0.0)$ & - & - \\
\hline Serum vitamin $D, \mathrm{nmol} / \mathrm{L}$ & $\begin{array}{l}74.50 \\
(58.00-93.25)\end{array}$ & $\begin{array}{l}76.0 \\
(61.0-99.5)\end{array}$ & $\begin{array}{l}74.0 \\
(29.0-86.0)\end{array}$ & $\begin{array}{l}73.0 \\
(62.5-90.5)\end{array}$ & 0.796 & 0.773 \\
\hline Serum NF-L, pg/mL & $6.1(4.5-8.9)$ & $8.0(5.8-9.6)$ & $5.1(4.3-5.9)$ & $4.6(4.1-5.3)$ & 0.011 & 0.390 \\
\hline
\end{tabular}

Abbreviations: BMI = body mass index; EDSS = Expanded Disability Status Scale; FSS = Fatigue Severity Scale; SDMT = Symbol Digit Modalities Test; NF-L = neurofilament light chain. RRMS = relapsing-remitting MS.

Numbers are median (interquartile range) unless otherwise stated.

a Unadjusted $p$ values are calculated using a Kruskal-Wallis test.

${ }^{b}$ Age-adjusted $p$ values are calculated with a likelihood ratio test between a linear model with only age and a linear model with age and the relevant baseline variable as predictors.

for 30 minutes at room temperature. Stained PBLs were washed, fixed in fresh $2 \%$ paraformaldehyde (Thermo Scientific, Waltham, MA) in Maxpar PBS for 10 minutes at room temperature, and then incubated in $125 \mathrm{nM}$ Cell- $\mathrm{ID}^{\mathrm{TM}}$ Intercalator-Ir in Maxpar Fix and Perm Buffer (Fluidigm) at $4^{\circ} \mathrm{C}$ overnight. We performed all centrifugation steps at room temperature at $800 \mathrm{~g}$.

Before mass cytometry analysis, PBLs were resuspended in 0.1× EQ Four Element Calibration Beads (Fluidigm) in Maxpar cell acquisition solution (Fluidigm) and filtered (Corning Falcon Test Tube with Cell Strainer Snap Cap,
Fisher Scientific, Hampton, NN). We used antibody binding QSC beads (Bangs Laboratories, Inc., catalog number 815A, Fishers, IN) to standardize signal intensities from anti-IgG4 (conjugated to ${ }^{169} \mathrm{Tm}$ ) and anti-CD49d (conjugated to ${ }^{141} \mathrm{Pr}$ ) as previously described in detail. ${ }^{12} \mathrm{We}$ analyzed PBL and QSC beads with the same standard settings on a Helios ${ }^{\circledR}$ mass cytometer (Fluidigm) after tuning (CyTOF Tuning Solution, Fluidigm) and calibration (EQ Four Element Calibration Beads, Fluidigm) according to the manufacture's guidelines. Healthy control PBLs served as a negative control for antiIgG4 in the absence of natalizumab, and patient PBLs incubated in vitro with natalizumab to an expected RO of $100 \%$ 
Table 2 Frequency of reported wearing-off symptoms

\begin{tabular}{lll}
\hline \multirow{2}{*}{ Symptom } & \multicolumn{2}{l}{ Wearing-off symptoms } \\
\cline { 2 - 3 } Fatigue & Sometimes & Regularly \\
\hline Psychological & $67 \%$ & $63 \%$ \\
\hline Walking difficulty & $33 \%$ & $25 \%$ \\
\hline Spasms & $11 \%$ & $25 \%$ \\
\hline Pain & $11 \%$ & $13 \%$ \\
\hline
\end{tabular}

served as positive controls. Further quality control experiments were performed as previously described in detail. ${ }^{12}$

\section{Data processing, analysis, and statistics}

After acquisition of QSC beads, we normalized (Fluidigm normalizer) and exported FCS files to Cytobank software (Cytobank, Inc., Beckman Coulter, Brea, CA) and created QSC bead standard curves (QuickCal template, Bangs Laboratories). After acquisition of PBL samples, we normalized (Fluidigm normalizer), debarcoded (Fluidigm Debarcoder), and exported the FSC files to Cytobank software for gating and downstream analysis (figure e-1, links.lww.com/NXI/A190). We performed clean-up gating to obtain single PBLs, and the data were arcsinh transformed with a scale argument of $5 .{ }^{13}$ We then performed 2 independent analyses for RO calculation in single PBLs: one was a manual analysis, and one used an unsupervised approach.

In the manual approach, we first identified the following 11 leukocyte subtypes of interest by manual gating: $\mathrm{CD} 8^{+}$central memory $\left(\mathrm{T}_{\mathrm{CM}}\right)$, effector memory $\left(\mathrm{T}_{\mathrm{EM}}\right)$, effector memory RA ( $\left.\mathrm{T}_{\mathrm{EMRA}}\right) \mathrm{T}$ cells; $\mathrm{CD} 4^{+} \mathrm{T}_{\mathrm{EM}}, \mathrm{T}_{\mathrm{CM}}$, and $\mathrm{T}_{\mathrm{EMRA}}$ cells; CD $34^{+}$cells; memory B cells; natural killer (NK) cells; monocytes; and conventional dendritic cells (cDCs). We then plotted the signal intensities (dual count 90th percentiles) of anti-IgG4 and anti-CD49d in each of these cell types with the QSC bead standard curves to obtain bead standardized values and calculated \%RO by the following formula:

$$
\% \mathrm{RO}=100 \times \frac{\mathrm{QSC} \text { bead standardized anti }-\mathrm{IgG} 4(169 \mathrm{Tm})}{\text { QSC bead standardized anti }-\mathrm{CD} 49 \mathrm{~d}(141 \mathrm{Pr})}
$$

We compared ROs in the leukocyte subtypes in different patient groups using a Kruskal-Wallis test.

In the unsupervised approach, we used $\mathrm{R}$ (version 3.4.3) to add an extra variable into the FSC files: the ratio between signal intensities of anti-IgG4 and anti-CD49d in each cell. This resulted in an RO estimate for each cell. For visualization of high-dimensional single-cell data, we performed automated dimensionality reduction with stochastic neighborhood embedding (viSNE, Cytobank). ${ }^{14}$ We analyzed the new RO variable with the cluster identification, characterization, and regression tool CITRUS (Cytobank), an algorithm that automatically identifies statistically significant differences between patient groups. ${ }^{15}$ We applied the correlative model Significance Analysis of Microarrays with a false discovery rate (adjusted for multiple hypothesis testing) of $1 \%$. CITRUS was run with 10 repetitions.

The relationship between baseline demographic variables and wearing-off was compared using a Kruskal-Wallis test. Statistical differences with $p<0.05$ were considered significant using a 2 -sided comparison. To test the age-corrected relationship between baseline variables and wearing-off, we used a likelihood ratio test between a linear model with only age and a linear model with age and the relevant baseline variable as predictors. We conducted a linear regression of the association between $\mathrm{RO}$ and body mass index (BMI) and used a $t$ test to assess whether the slope was significantly different from zero. We used $\mathrm{R}$ version $3.4 .3^{16}$ for statistical analysis and correlation plots.

\section{Data availability}

FCS files from anonymized patient PBL samples can be accessed in the Flow Repository (ID: FR-FCM-Z2A9).

\section{Results}

\section{Patient characteristics}

Of the 45 patients who were eligible for inclusion, 40 (89\%) consented to participate in the study. Of 5 (11\%) nonconsenting patients, 1 refused participation, and 4 had infusion time points outside of the opening hours of the routine laboratory where blood samples were collected. Eight (20.0\%) of the 40 participating patients reported having wearing-off symptoms regularly at the end of every dosing interval, 9 (22.5\%) sometimes did, and 23 (57.5\%) reported never having wearing-off symptoms (table 1). The most frequent wearing-off symptom was fatigue (table 2). Patients who regularly had wearing-off symptoms had significantly higher BMI and higher frequency of sick leave than patients who never or only sometimes experienced such symptoms (table 1). After age adjustment, weight was also significantly increased in patients with wearing-off symptoms regularly, whereas height was increased in patients with symptoms only sometimes. None of the other demographic or clinical patient characteristics were significantly different between the groups, and none of the included patients had clinical relapses or new lesions on MRI in the year before inclusion in the study. Age-adjusted median serum NF-L levels were similar between groups. There was no association between NF-L and BMI (data not shown).

\section{Receptor occupancy}

Manual gating of PBLs correlated well with the automated mapping with viSNE (figure 1A). We observed a broad range of natalizumab RO values. The median $\mathrm{RO}$ values in all leukocyte subtypes before infusion and in 10 of 11 leukocyte subtypes after infusion (figure 1B) were lower in patients who regularly experienced wearing-off symptoms than in patients who never or only sometimes experienced such symptoms. The differences were statistically significant in $\mathrm{CD}^{+} \mathrm{T}_{\mathrm{EM}}, \mathrm{CD}^{+} \mathrm{T}_{\mathrm{EM}}$, and 
A

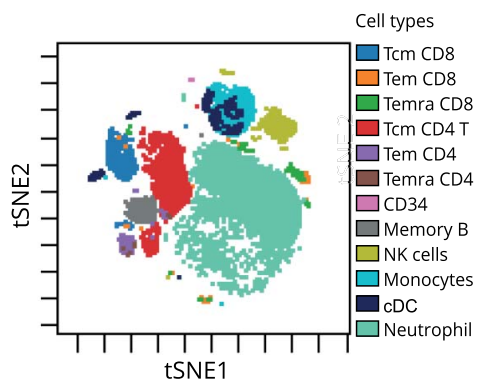

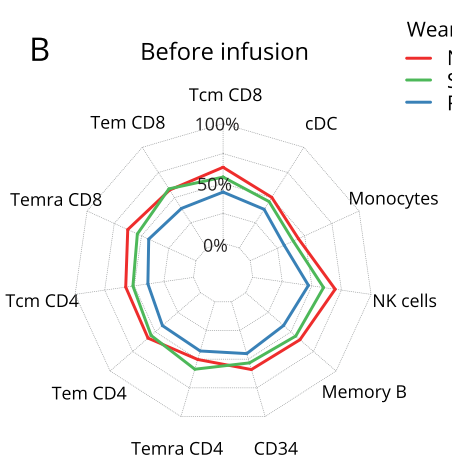

$\begin{array}{lc}\text { Wearing-off } & \\ \text { - Never } & \text { After infusion } \\ \text { - Sometimes } & \text { Tcm CD8 }\end{array}$

Regularly Tem CD8 $100 \% \quad$ CDC

C
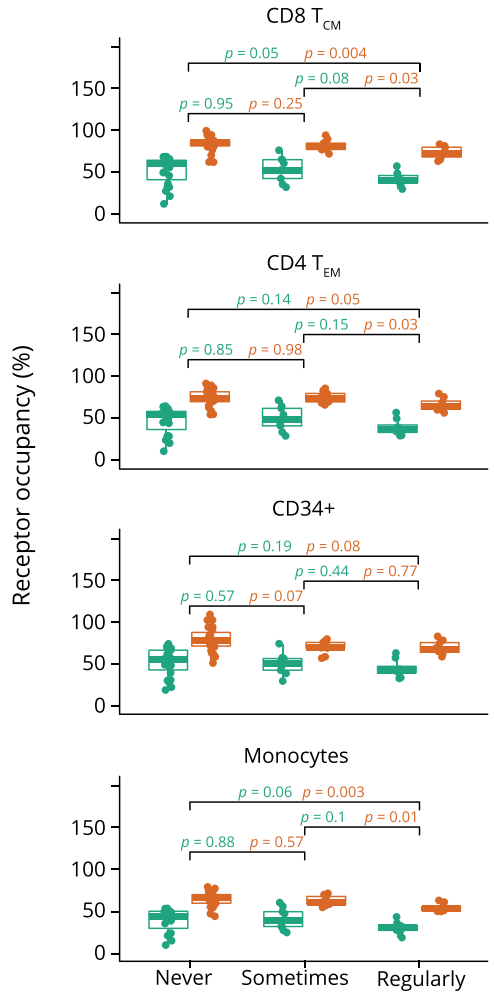
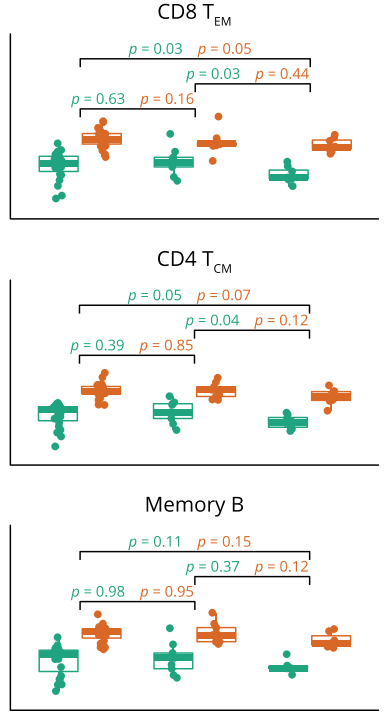

CDC
CD34
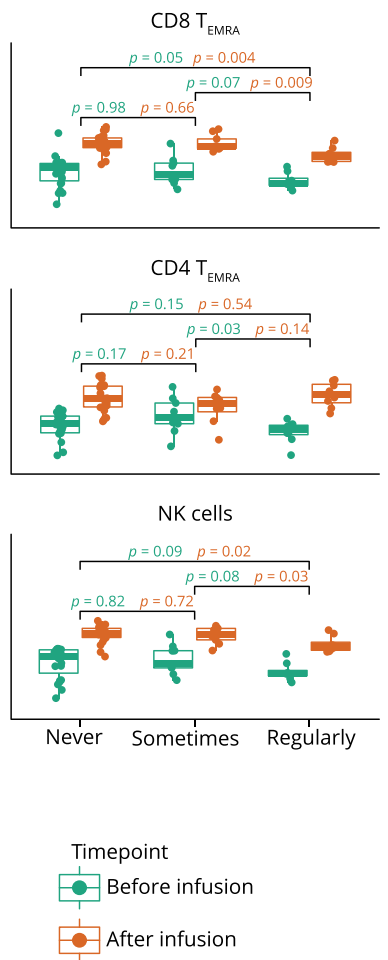

After infusion

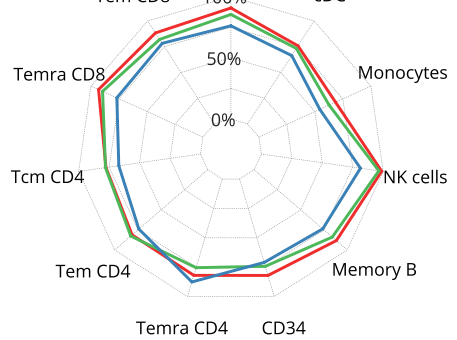

Wearing-off

D $\begin{aligned} & \text { Before } \\ & \text { infusion }\end{aligned}$
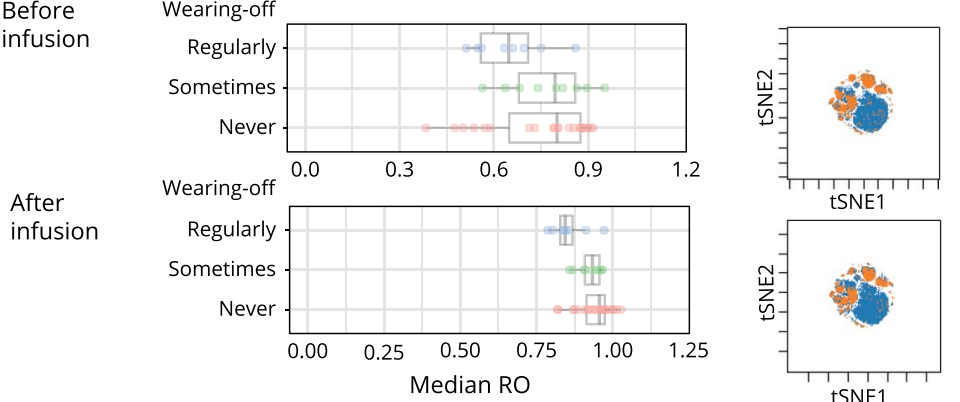

All cells

Significant clusters

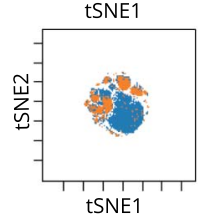

(A) Manually gated PBLs visualized on a viSNE map. RO was analyzed in 11 cell subtypes: $C_{D} 8^{+}$central memory (T $T_{C M}$ ), effector memory ( $T_{E M}$ ), effector memory RA ( $T_{E M R A}$ ) cells; CD4 ${ }^{+} T_{E M}, T_{C M}$, and $T_{E M R A}$ cells; CD34 ${ }^{+}$cells; memory B cells; natural killer (NK) cells; monocytes; and conventional dendritic cells (cDCs). Neutrophils were not included in RO analysis. (B) Spider plot of median RO values in 11 cell subtypes in patients before and after natalizumab infusion. (C) RO values in 11 cell subtypes before and after natalizumab infusion. $p$ values (Kruskal-Wallis test) comparing ROs in different wearing-off groups. (D) Left: median RO values in cell clusters significantly different between wearing-off groups (SAM analysis in CITRUS). Right: significant cell clusters are visualized on the viSNE map. PBL = peripheral blood leukocyte; SAM = Significance Analysis of Microarrays. 
$\mathrm{CD} 4^{+} \mathrm{T}_{\mathrm{EMRA}}$ cells before infusion and in $\mathrm{CD} 8^{+} \mathrm{T}_{\mathrm{CM}}$, $\mathrm{CD} 8^{+}$ $\mathrm{T}_{\mathrm{EMRA}} \mathrm{CD} 4^{+} \mathrm{T}_{\mathrm{CM}}$ cells, NK cells, monocytes, and cDCs after infusion (figure 1C). Furthermore, in $\mathrm{CD}^{+}$and $\mathrm{CD}^{+} \mathrm{T}$ cells not stratified into subtypes, $\mathrm{RO}$ was significantly lower in both $\mathrm{CD}^{+}$and $\mathrm{CD}^{+} \mathrm{T}$ cells before infusion and in $\mathrm{CD} 8^{+} \mathrm{T}$ cells after infusion in patients who regularly had wearing-off symptoms (figure e-2, links.lww.com/NXI/A190). Unsupervised analysis of median ROs with CITRUS also showed lower median natalizumab ROs in patients with regular wearing-off symptoms (figure 1D). Neither of the 2 analysis approaches showed significant differences between patients reporting wearing-off symptoms sometimes and never.

High $\mathrm{BMI}$ was associated with significantly lower $\mathrm{RO}$ in $\mathrm{CD} 8^{+}$ $\mathrm{T}_{\mathrm{EM}}$ cells and cDCs before infusion and in $\mathrm{CD} 8^{+} \mathrm{T}_{\mathrm{EMRA}}$ cells, $\mathrm{CD} 34^{+}$cells, and monocytes after infusion (figure 2).

\section{Discussion}

Natalizumab prevents disease activity in RRMS and has positive effects on subjective symptoms such as mood, fatigue, and cognitive function. ${ }^{17,18}$ However, subjective wearing-off symptoms at the end of the 4-week interval are frequently reported by patients. In this study, wearing-off symptoms were reported by $42.5 \%$ of the patients ( $20.0 \%$ regularly and $22.5 \%$ only sometimes). We found lower natalizumab ROs in patients who regularly experienced wearing-off symptoms compared with patients who reported such symptoms never or only sometimes. The result was replicated in 2 separate data analysis pipelines. Furthermore, patients who reported regularly experiencing wearing-off symptoms had higher median body weight and BMI and higher sick leave frequency than those who rarely or never experienced such symptoms. Median height was increased in patients with symptoms only sometimes. Other clinical and demographic factors were similar between the patient groups. High BMI was associated with low RO in several leukocyte subtypes.

The main limitation of our study is the small patient cohort. As a consequence of this limited statistical power, we were only able to detect large effects and acknowledge that there may be associations of smaller effect size that went unnoticed. Wearingoff symptoms were less frequent in our study than the prevalence of 54\%-63\% reported in other studies, but as previously reported, the most frequent wearing-off symptom was fatigue. ${ }^{2-5}$ In contrast to our results, a recent study found no association between the wearing-off effect and natalizumab RO or patient characteristics. ${ }^{5}$ The previously reported study used flow cytometry to measure $\mathrm{RO}$ in $\mathrm{CD} 8^{+} \mathrm{T}_{\mathrm{EM}}$ cells and $\mathrm{CD} 8^{+}$ effector $\mathrm{T}$ cells. By using high-parameter mass cytometry, we were able to measure RO in 11 cell subtypes simultaneously. We found that patients who regularly experienced wearing-off symptoms had higher BMI than those who did not, and we also observed an association between high BMI and low RO. Body weight was higher in our cohort than in the previous study (median 75.0 vs mean $72.9 \mathrm{~kg}$ ) and was even more pronounced in the group with wearing-off symptoms regularly (median 81.5 vs mean $74.6 \mathrm{~kg}$ ). van Kempen et al. ${ }^{5}$ reported nonsignificant trends similar to our significant results. Our wearing-off population had higher body weight than theirs, which may explain why we observed statistically significant differences despite our small cohort size. The association between high BMI and low RO suggests that high BMI, by decreasing natalizumab RO, may be the underlying cause of the wearing-off phenomenon. Others have previously reported such an association between low natalizumab RO and high body weight or BMI, and some have suggested that the dose of natalizumab should be adjusted for body weight. ${ }^{6,19,20}$ We found no associations between wearing-off symptoms and disease activity markers such as clinical relapses, new lesions detected by MRI in the past year, or serum NF-L levels. ${ }^{21}$

Figure 2 Linear regression analysis demonstrates an association between RO and BMI
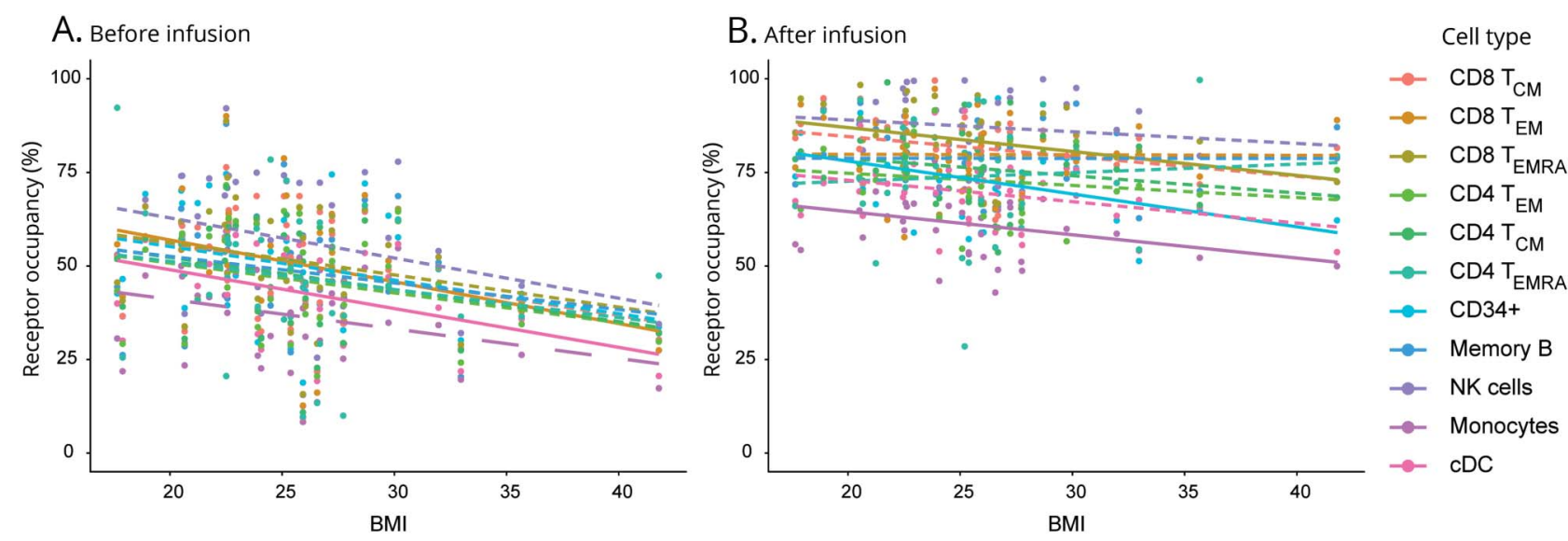

Plot of receptor occupancies $(A)$ before and $(B)$ after infusion for indicated cell types as a function of BMI. Solid lines have slopes that are significantly different from zero $(p<0.05)$, and dashed lines have slopes that are not significantly different from zero. BMI = body mass index; RO = receptor occupancy. 
As also reported by others, ${ }^{19}$ we observed large interindividual variations in natalizumab $\mathrm{RO}$, and not all patients with low RO had high BMI. A previous study reported that body weight only partly predicts variability in natalizumab RO and suggested other factors such as density and turnover of $\alpha 4 \beta 1$ integrin that may drive the variability. ${ }^{22}$

It has been hypothesized that cytokines could induce the wearing-off symptoms. ${ }^{4,5}$ We speculate that lower natalizumab RO at the end of the dosing interval could increase the migratory capacity of cytokine-producing leukocytes into the CNS resulting in the wearing-off symptoms. We found significantly lower $\mathrm{RO}$ in the T-cell subtypes $\mathrm{CD} 8^{+} \mathrm{T}_{\mathrm{EM}}, \mathrm{CD} 4^{+}$ $\mathrm{T}_{\mathrm{EM}}$, and $\mathrm{CD} 4^{+} \mathrm{T}_{\mathrm{EMRA}}$ cells before infusion in patients who regularly had wearing-off symptoms. $\mathrm{T}_{\mathrm{EM}}$ and $\mathrm{T}_{\mathrm{EMRA}}$ cells home to the site of inflammation where they have effector functions such as secretion of proinflammatory cytokines and cytotoxicity; in contrast, $\mathrm{T}_{\mathrm{CM}}$ cells and naive $\mathrm{T}$ cells home to secondary lymphoid organs. ${ }^{23,24}$

Our results suggest that low RO may be a contributing factor to the wearing-off phenomenon and that higher BMI may be an underlying cause. This supports the suggestion that natalizumab dosing should be personalized. Personalization has been mainly focused on extended interval dosing (EID). ${ }^{19}$ This has particularly been driven by the risk of progressive multifocal leukoencephalopathy (PML), a serious complication of natalizumab therapy in patients previously exposed to JC virus. ${ }^{25}$ Retrospective studies of off-label treatment with EID have shown maintained efficacy ${ }^{26,27}$ and reduced PML risk $^{28}$ compared with standard interval dosing. However, these studies are limited by possible selection bias due to nonrandomized design, and the efficacy and safety of EID is not fully known. As patients who regularly experience wearing-off symptoms already have lower $\mathrm{RO}$ and report symptoms at the end of dosing intervals, extending dosing intervals could increase the risk of disease activity. We therefore do not recommend EID in patients reporting wearing-off symptoms regularly, as this could lead to an even lower RO at the end of the interval than observed with standard dosing. ${ }^{6,19}$ Further studies should investigate whether wearing-off symptoms are associated with increased risk of RRMS disease activity and whether increasing RO by reduced dosing intervals or weight loss may mitigate the symptoms.

\section{Acknowledgment}

The authors thank Fritz og Ingrid Nilsens legat for financial research support and Hanne Linda Nakkestad at the Neurological Research Laboratory at Haukeland University Hospital for performing SiMOA analyses. The mass cytometry was performed at the Flow Cytometry Core Facility, Department of Clinical Science, University of Bergen. The Helios mass cytometer was funded by the Bergen Research Foundation. Neuro-SysMed is jointly hosted by Haukeland University Hospital and University of Bergen and supported as a Centre for Clinical Treatment Research (FKB) by grants from The Research Council of Norway, project number 288164.

\section{Study funding}

Supported by Fritz og Ingrid Nilsens legat for Forskning på Multippel sklerose.

\section{Disclosure}

G.H. Bringeland has received research support from Novartis and institutional support from the Regional Heath Authority of Western Norway. N. Blaser reports no disclosures. K.-M. Myhr has received grants and personal fees from Biogen and Novartis; personal fees from Genzyme, Roche, Almirall, and Merck; personal fees and nonfinancial support from Teva; and a research grant from the Norwegian Research Council (grant number 288164). C.A. Vedeler has received institutional support from the Regional Heath Authority of Western Norway and research grant support from the Norwegian Research Council (grant number 288164). Dr. Gavasso has received institutional support from the Regional Heath Authority of Western Norway. Go to Neurology.org/ $\mathrm{NN}$ for full disclosures.

\section{Publication history}

Received by Neurology: Neuroimmunology \& Neuroinflammation October 22, 2019. Accepted in final form December 20, 2019.

\section{Appendix Authors}

\begin{tabular}{|c|c|c|c|}
\hline Name & Location & Role & Contribution \\
\hline $\begin{array}{l}\text { Gerd Haga } \\
\text { Bringeland, } \\
\text { MD }\end{array}$ & $\begin{array}{l}\text { University of Bergen, } \\
\text { and Haukeland } \\
\text { University Hospital, } \\
\text { Bergen, Norway }\end{array}$ & Author & $\begin{array}{l}\text { Conception and } \\
\text { design of the study; } \\
\text { major role in the } \\
\text { acquisition of data; } \\
\text { interpretation of data; } \\
\text { analysis of data; and } \\
\text { revision of the } \\
\text { manuscript for } \\
\text { intellectual content }\end{array}$ \\
\hline $\begin{array}{l}\text { Nello } \\
\text { Blaser, PhD }\end{array}$ & $\begin{array}{l}\text { University of Bergen, } \\
\text { Bergen, Norway }\end{array}$ & Author & $\begin{array}{l}\text { Interpretation of data; } \\
\text { analysis of data; and } \\
\text { revision of the } \\
\text { manuscript for } \\
\text { intellectual content }\end{array}$ \\
\hline $\begin{array}{l}\text { Kjell- } \\
\text { Morten } \\
\text { Myhr, MD, } \\
\text { PhD }\end{array}$ & $\begin{array}{l}\text { University of Bergen, } \\
\text { and Haukeland } \\
\text { University Hospital, } \\
\text { Bergen, Norway }\end{array}$ & Author & $\begin{array}{l}\text { Conception and } \\
\text { design of the study } \\
\text { and revision of the } \\
\text { manuscript for } \\
\text { intellectual content }\end{array}$ \\
\hline $\begin{array}{l}\text { Christian } \\
\text { Alexander } \\
\text { Vedeler, } \\
\text { MD, PhD }\end{array}$ & $\begin{array}{l}\text { University of Bergen, } \\
\text { and Haukeland } \\
\text { University Hospital, } \\
\text { Bergen, Norway }\end{array}$ & Author & $\begin{array}{l}\text { Conception and } \\
\text { design of the study } \\
\text { and revision of the } \\
\text { manuscript for } \\
\text { intellectual content }\end{array}$ \\
\hline $\begin{array}{l}\text { Sonia } \\
\text { Gavasso, } \\
\text { PhD }\end{array}$ & $\begin{array}{l}\text { University of Bergen, } \\
\text { and Haukeland } \\
\text { University Hospital, } \\
\text { Bergen, Norway }\end{array}$ & Author & $\begin{array}{l}\text { Conception and } \\
\text { design of the study; } \\
\text { interpretation of data; } \\
\text { and revision of the } \\
\text { manuscript for } \\
\text { intellectual content }\end{array}$ \\
\hline
\end{tabular}




\section{References}

1. Polman CH, O'Connor PW, Havrdova E, et al. A randomized, placebo-controlled trial of natalizumab for relapsing multiple sclerosis. N Engl J Med 2006;354:899-910.

2. Katz J, Lathi E, Heyda L. Characterizing the Natalizumab "Wearing off" Effect [abstract]. ACTRIMS meeting; Poster DX36; 2014.

3. Gudesblatt M, Zarif M, Bumstead B, et al. Multiple sclerosis and natalizumab: "between the dose symptoms" [abstract 982]. Mult Scler 2012;18(suppl 14):P982.

4. Ratchford JN, Brock-Simmons R, Augsburger A, et al. Multiple sclerosis symptom recrudescence at the end of the natalizumab dosing cycle. Int J MS Care 2014;16:92-98.

5. van Kempen ZLE, Doesburg D, Dekker I, et al. The natalizumab wearing-off effect: end of natalizumab cycle; recurrence of MS symptoms. Neurology 2019;93:e1579-e1586.

6. Punet-Ortiz J, Hervas-Garcia JV, Teniente-Serra A, et al. Monitoring CD49d receptor occupancy: a method to optimize and personalize natalizumab therapy in multiple sclerosis patients. Cytometry B Clin Cytom 2018;94:327-333.

7. Bandura DR, Baranov VI, Ornatsky OI, et al. Mass cytometry: technique for real time single cell multitarget immunoassay based on inductively coupled plasma time-offlight mass spectrometry. Anal Chem 2009;81:6813-6822.

8. Smith A. Symbol digit modalities test: Manual. Los Angeles, CA: Western Psychological Services; 1982

9. Kurtzke JF. Rating neurologic impairment in multiple sclerosis: an expanded disability status scale (EDSS). Neurology 1983;33:1444-1452.

10. Krupp LB, LaRocca NG, Muir-Nash J, Steinberg AD. The fatigue severity scale. Application to patients with multiple sclerosis and systemic lupus erythematosus. Arch Neurol 1989;46:1121-1123.

11. Rahman AH, Tordesillas L, Berin MC. Heparin reduces nonspecific eosinophil staining artifacts in mass cytometry experiments. Cytometry A 2016;89:601-607.

12. Bringeland GH, Bader L, Blaser N, et al. Optimization of receptor occupancy assays in mass cytometry: standardization across channels with QSC beads. Cytometry A 2019; 95:314-322.

13. Finak G, Perez JM, Weng A, Gottardo R. Optimizing transformations for automated, high throughput analysis of flow cytometry data. BMC Bioinformatics 2010;11:546.

14. Amir el $\mathrm{AD}$, Davis $\mathrm{KL}$, Tadmor $\mathrm{MD}$, et al. viSNE enables visualization of high dimensional single-cell data and reveals phenotypic heterogeneity of leukemia. Nat Biotechnol 2013;31:545-552.
15. Bruggner RV, Bodenmiller B, Dill DL, Tibshirani RJ, Nolan GP. Automated identification of stratifying signatures in cellular subpopulations. P Natl Acad Sci USA 2014; 111:E2770-E2777.

16. R: A Language and Environment for Statistical Computing [computer program] Vienna: R Foundation for Statistical Computing; 2017.

17. Iaffaldano P, Viterbo RG, Paolicelli D, et al. Impact of natalizumab on cognitive performances and fatigue in relapsing multiple sclerosis: a prospective, open-label, two years observational study. PLoS One 2012;7:e35843.

18. Morrow SA, O'Connor PW, Polman $\mathrm{CH}$, et al. Evaluation of the symbol digit modalities test (SDMT) and MS neuropsychological screening questionnaire (MSNQ) in natalizumab-treated MS patients over 48 weeks. Mult Scler 2010;16:1385-1392.

19. Foley JF, Goelz S, Hoyt T, Christensen A, Metzger RR. Evaluation of natalizumab pharmacokinetics and pharmacodynamics with standard and extended interval dosing. Mult Scler Relat Dis 2019;31:65-71.

20. Tanaka M, Kinoshita M, Foley JF, Tanaka K, Kira J, Carroll WM. Body weight-based natalizumab treatment in adult patients with multiple sclerosis. J Neurol 2015;262:781-782.

21. Varhaug KN, Torkildsen O, Myhr KM, Vedeler CA. Neurofilament light chain as a biomarker in multiple sclerosis. Front Neurol 2019;10:338.

22. Muralidharan KK, Kuesters G, Plavina T, et al. Population pharmacokinetics and target engagement of natalizumab in patients with multiple sclerosis. J Clin Pharmacol 2017;57:1017-1030.

23. Mahnke YD, Brodie TM, Sallusto F, Roederer M, Lugli E. The who's who of T-cell differentiation: human memory T-cell subsets. Eur J Immunol 2013;43:2797-2809.

24. Sallusto F, Geginat J, Lanzavecchia A. Central memory and effector memory T cell subsets: function, generation, and maintenance. Annu Rev Immunol 2004;22: 745-763.

25. Bloomgren G, Richman S, Hotermans C, et al. Risk of natalizumab-associated progressive multifocal leukoencephalopathy. N Engl J Med 2012;366:1870-1880.

26. Bomprezzi R, Pawate S. Extended interval dosing of natalizumab: a two-center, 7-year experience. Ther Adv Neurol Disord 2014;7:227-231.

27. Zhovtis Ryerson L, Frohman TC, Foley J, et al. Extended interval dosing of natalizumab in multiple sclerosis. J Neurol Neurosurg Psychiatry 2016;87:885-889.

28. Ryerson LZ, Foley J, Chang I, et al. Risk of natalizumab-associated PML in patients with MS is reduced with extended interval dosing. Neurology 2019;93:e1452-e1462. 


\section{Neurology \\ Neuroimmunology \& Neuroinflammation}

\section{Wearing-off at the end of natalizumab dosing intervals is associated with low receptor occupancy \\ Gerd Haga Bringeland, Nello Blaser, Kjell-Morten Myhr, et al. \\ Neurol Neuroimmunol Neuroinflamm 2020;7; \\ DOI 10.1212/NXI.0000000000000678}

This information is current as of February 4, 2020

\begin{abstract}
Updated Information \&
Services

References

Citations

Subspecialty Collections

Permissions \& Licensing

Reprints

including high resolution figures, can be found at: http://nn.neurology.org/content/7/3/e678.full.html

This article cites 25 articles, 2 of which you can access for free at: http://nn.neurology.org/content/7/3/e678.full.html\#\#ref-list-1

This article has been cited by 2 HighWire-hosted articles: http://nn.neurology.org/content/7/3/e678.full.html\#\#otherarticles

This article, along with others on similar topics, appears in the following collection(s):

Multiple sclerosis

http://nn.neurology.org//cgi/collection/multiple_sclerosis

Information about reproducing this article in parts (figures,tables) or in its entirety can be found online at:

http://nn.neurology.org/misc/about.xhtml\#permissions

Information about ordering reprints can be found online:

http://nn.neurology.org/misc/addir.xhtml\#reprintsus
\end{abstract}

Neurol Neuroimmunol Neuroinflamm is an official journal of the American Academy of Neurology.

Published since April 2014, it is an open-access, online-only, continuous publication journal. Copyright

Copyright $\odot 2020$ The Author(s). Published by Wolters Kluwer Health, Inc. on behalf of the American

Academy of Neurology.. All rights reserved. Online ISSN: 2332-7812.

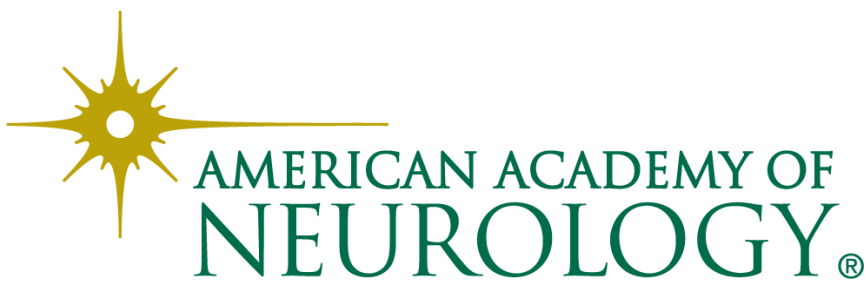

